\title{
HEXACHLOROBENZENE EFFECT ON MICROBIOCENOSES OF DIFFERENT SOIL TYPES
}

\author{
M.I. Dimova, N.A. Yamborko, G.O. Iutynska \\ Zabolotny Institute of Microbiology and Virology, NAS of Ukraine, \\ 154 Acad. Zabolotny Str., Kyiv, 03143, Ukraine \\ mdildiv@gmail.com
}

\begin{abstract}
Cyclic organochlorine compounds, including hexachlorobenzene (HCB) being among the most dangerous persistent organic pollutants, have accumulated in the environment due to their widespread use for chemical plant protection. The issue of different HCB contamination influence on soil microbial communities is relevant and insufficiently studied. The aim was to investigate the reaction of microbial communities to HCB contamination of chernozem, dark-kastanozem and sod-podzolic soils of Ukraine. Methods. Model laboratory experiments, microbiological (determination of the microbial quantity on agar nutrient media), chemical (adsorption method for the study of basal and substrate-induced respiration of soil microbiota), and statistical methods. Results. Contamination of chernozem, dark-kastanozem and sod-podzolic soils of Ukraine with HCB in doses from 10 to 10,000 maximum permissible concentrations adversely affected the microbial quantity of major ecological and trophic groups, among which the most sensitive were phosphate-mobilizing bacteria and streptomycetes. In contaminated soils, the structure of the microbiocenoses was disturbed, the general biological activity was reduced-the basal respiration rate by $28.5-62.7 \%$ and the substrate-induced by 2-3 times, the accumulation of microbial biomass decreased by 1.5-4.3 times. The HCB contamination caused the main impact on the dispersion of microbial quantity (by 61-95\%), the influence of soil type was smaller (1-24\%). Conclusions. Microbiocenoses of chernozem, dark-kastanozem, sod-podzolic soils in intensive land use systems are vulnerable to HCB contamination in doses from 10 to 10.000 maximum permissible concentrations. The most sensitive phosphate-mobilizing bacteria and streptomycetes can be used as indicators in monitoring of organochlorine contaminated soils. Under the action of pesticide loading, microbial respiration and accumulation of microbial biomass are suppressed. The negative reaction of microbial communities to HCB contamination indicates the need for remediation measures to recovery the microbiota and soil fertility.
\end{abstract}

Keywords: microbial communities, basal and substrate-induced respiration, microbial biomass, hexachlorobenzene, contamination.

In recent decades, organochlorine pesticides have been widely used in agriculture for chemical protection of plants from diseases and pests, which has led to their accumulation in large quantities in soils. Organochlorine pesticides are compounds that chemically are halogenated derivatives of polycyclic and aliphatic hydrocarbons, on the basis of which a number of common insecticides have been developed, such as dichlorodiphenyltrichloroethane (DDT), hexachlorocyclohexane $(\mathrm{HCH})$, hexachlorane (Lindane), aldrin, and sodium trichloroacetate (herbicides Acetlur and Phenacyt). Most of them have high toxicity and persistence in the environment, the property of bioaccumulation, which leads to functional disruption of soil agroecosystems [1].
One of the most common organochlorine pesticides is hexachlorobenzene (HCB), which accumulates in the soil after plant treatment and as industrial waste. In addition, chlorobenzenes are known to be used in large quantities as chemical intermediates in the manufacture of degreasers, solvents and deodorants. By getting HCB into the environment, it disrupts the state of ecosystems [2]. Soil microbial communities respond to pesticide load in terms of microbial quantity, total microbial biomass and the ratio of functional groups of microorganisms in the biocenosis $[3,4]$.

Analysis of the above literature data indicates that soil microorganisms are sensitive bioindicators of organochlorine contamination, due to their ability to quickly respond to changes in the environment [2]. The study of soil microbial communities' response to $\mathrm{HCB}$ contamination 
deserves attention of researchers. The different soil types are known to be characterized by some specific conditions affecting the formation and functioning of the microbiota. The resistance of microbial communities of different soil types in Ukraine to HCB contamination remains insufficient studied. Therefore, the aim of this study was to establish the patterns of HCB influence on the microbiota of most common soil types in Ukraine, such as chernozem, sod-podzolic and darkkastanozem.

Materials and methods. The research object was the reaction of microbial groups to contamination of chernozem, dark-kastanozem and sod-podzolic soils of Ukraine with different HCB doses.

Studied samples of different soil types were taken in agrocenoses under intensive land use farming systems. The studied soils had the following characteristics:

chernozem soil (Kyiv region): $\mathrm{pH} 7.6 \pm 0.3$, nutrient content, $\mathrm{mg} \cdot \mathrm{kg}^{-1}$ : alkaline hydrolyzed nitrogen $-119.2 \pm 11.9$, mobile phosphorus $-60.9 \pm$ \pm 9 , exchangeable potassium $-168.8 \pm 16.9$;

dark-kastanozem soil (Kherson region): $\mathrm{pH} 6.4 \pm$ \pm 0.15 , nutrient content, $\mathrm{mg} \cdot \mathrm{kg}^{-1}$ : alkaline hydrolyzed nitrogen $-79.2 \pm 8.0$, mobile phosphorus $235 \pm 28.2$, exchangeable potassium $-77.5 \pm 11.6$;

sod-podzolic soil (Chernihiv region): $\mathrm{pH} 4.0 \pm$ \pm 0.15 , nutrient content, $\mathrm{mg} \cdot \mathrm{kg}^{-1}$ : alkaline hydrolyzed nitrogen $-79.2 \pm 8.0$, mobile phosphorus $332.3 \pm 49.8$, exchangeable potassium $-136.3 \pm$ \pm 13.6 .

Experiments were conducted in laboratory conditions. $250 \mathrm{~g}$ of sieved soil samples (slit diameter of sieve was $2 \mathrm{~mm}$ ) were added to plastic containers, moistened to $70 \%$ of the total moisture content, and maintained for 12 days to stabilize biological processes.

The soil prepared in this way was experimentally contaminated with industrial waste of the chemical industrial complex "Oriana-Galev" from Kalush, Ivano-Frankivsk region, which contained $90 \%$ $\mathrm{HCB}$ and $10 \%$ of various industrial impurities [5]. The amount of added pollutant was calculated by the content of HCB in the following doses of maximum permissible concentrations (MPC): $10,500,1000,2500,5000,10000$, given that the MPC of HCB is $0.03 \mathrm{mg} \mathrm{kg}^{-1}$ of soil [6]. Control samples did not contain HCB. Experimental and control samples were incubated for 60 days at room temperature $\left(+20 \pm 2^{\circ} \mathrm{C}\right)$, maintaining a humidity of $70 \%$ of total moisture content. At the end of the experiment microbiological researches of the soil were conducted. The quantity of microorganisms was assessed by the method of sowing ten-fold dilutions of the soil suspension on agarified nutrient media and assessing the number of colonyforming units (CFUs) per gram of dry soil, taking into account its moisture content. The quantity of pedotrophic microorganisms was determined on soil agar, amylolytic - starch-ammonia agar, oligonitrotrophic and nitrogen fixing - Ashbee medium, phosphate-mobilizing - on the Menkina's medium with phenolphthalein sodium phosphate, streptomycetes - on glucose-potato agar, micromycetes - on the Chapek's medium [7, 8]. The quantity of ammonifying microorganisms was determined on peptone-glucose medium M17 (Oxoid, United Kingdom).

The total biological activity of the soil microbiota was assessed by the rate of basal and substrate-induced respiration using the adsorption method; the obtained results were used to calculate the content of microbial biomass $[9,10]$. The coefficient of soil microbial respiration (Qr) was determined by the method [11]. The mineralization coefficient was calculated by Mishustin and Runov method[12], the pedotrophic index - according to Nikitin and Nikitina method [13].

Statistical assaying of the results was performed using Microsoft Excel software to determine the deviation of confidence interval, nonparametric correlation coefficients and two-way analysis of variance [Microsoft Excel, ANOVA].

Results. In our research it was shown that three studied soil types were different in biogenicity by value of the microbial quantity of different ecological-trophic and some systematic groups. The highest quantity of prokaryotic microorganisms was in chernozem, which exceeded that in dark-kastanozem and sod-podzolic soils by 1.7 and 3.0 times, respectively (Fig. 1). On the contrary, the highest quantity of micromycetes was found in sod-podzolic soil $-1.7 \cdot 10^{6} \mathrm{CFU} \mathrm{g}^{-1}$ of soil, which was higher than their content in chernozem and kastanozem soils by 49 and $46 \%$, respectively. It should also be noted that pedotrophic microorganisms were dominated in the microbial communities of all studied soils. They perform transformation of water-soluble humus fractions. Pedotrophic microorganisms are the most common group, which adequately images the general development of soil microbiota; they play a significant role in the formation of soil fertility. 
The obtained data results about the development of microbiota under contaminating conditions with different toxicant doses showed that the microbiocenoses of the studied soils are not resistant to HCB contamination. Phosphatemobilizing bacteria and streptomycetes were among the most sensitive (Fig. 2). Phosphate-mobilizing bacteria are able to decompose hard-to-reach organophosphates to phosphatases and inorganic phosphates through the production of organic acids and convert them into phosphorus forms available to plants. Under the action of a low contamination dose of $10 \mathrm{MPC}$, the quantity of these bacteria in all soil types varied insignificantly, but with increasing pesticide load, a significant inhibiting of phosphatemobilizing bacteria development was observed.

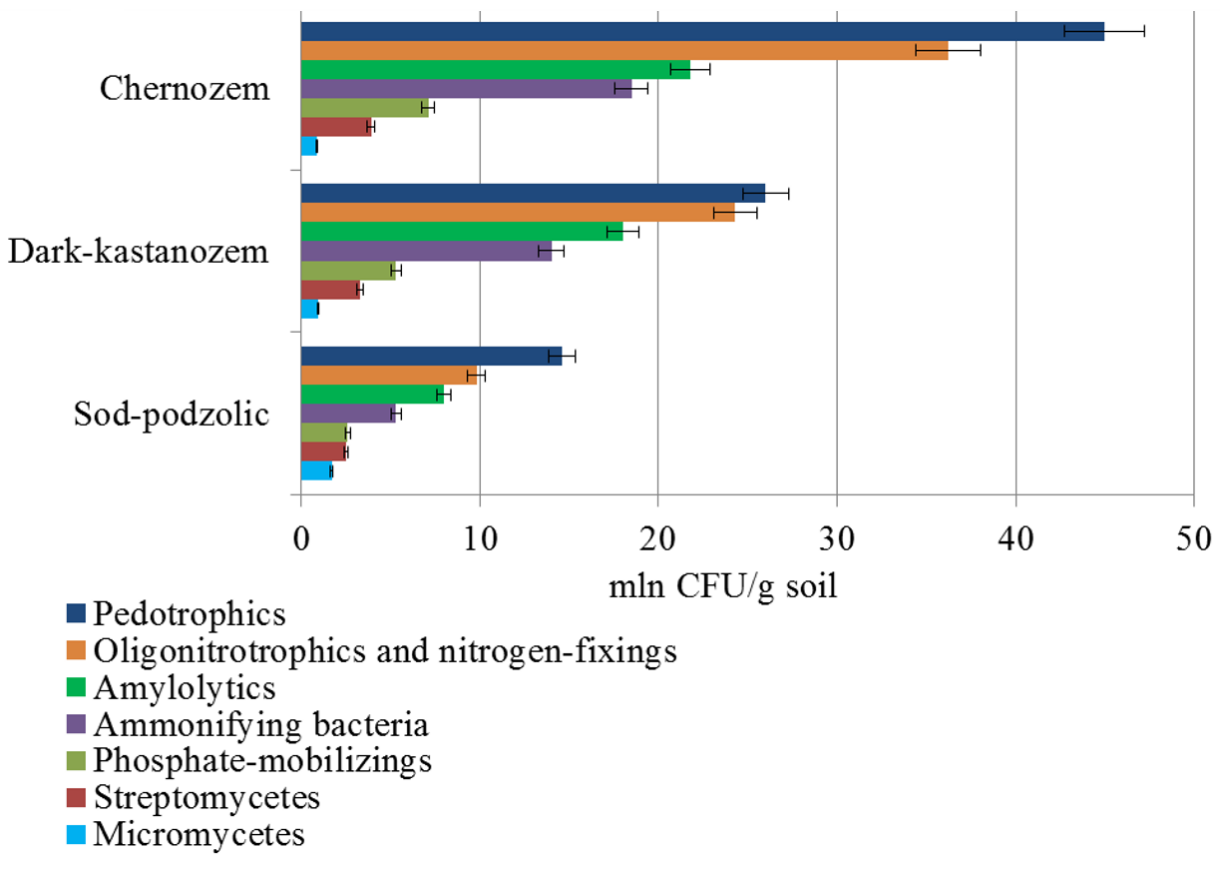

F i g. 1. The microbial quantity of ecological-trophic and systematic groups in different soil types

Under the action of contamination dose of 500 MPC in dark-kastanozem and sod-podzolic soils, their number decreased by 46.1 and $40.6 \%$ of the control, respectively; less suppression was observed in chernozem soil - by $23.3 \%$. At the highest pollution dose of $10.000 \mathrm{MPC}$, the quantity of phosphate-mobilizers decreased in all soil types: in chernozem - by 47.9 , in kastanozem by $75 \%$, in sod-podzolic - by $82.7 \%$ of control, therefore, the smallest suppression was observed in chernozem soil (Fig. 2, A).

Streptomycetes are actively involved in soil processes, such as mineralization and transformation of organic matter; due to the ability to synthesize a wide range of biologically active compounds, they play an important role in the formation of productive microbial-plant systems and increase phytopathogens suppression in the soil [14]. The quantity of streptomycetes at a dose of 500 MPC in all soil types decreased by $52.5-$ $56.2 \%$ of control, and with a further increase in the dose of contamination from 2500 to 10000 MPC - decreased to critical values by $69.6-92 \%$ compared to uncontaminated control (Fig. 2, B). Consequently, phosphate-mobilizing bacteria and streptomycetes that determined as the most sensitive microorganisms can be indicators for monitoring soils contaminated with organochlorine pesticides.

Amylolytic bacteria involved in transformation of plant residues have shown slightly greater resistance to HCB. At a contamination dose of 500 MPC, this group showed the greatest resistance in chernozem, where there was a lightly decrease in the quantity of these bacteria by $21 \%$ compared to control, while in dark-kastanozem and sodpodzolic soils at the same pollution dose - by 32.8 and $38.0 \%$ respectively. Amylolytic bacteria showed almost the same sensitivity in different soils at a contamination dose of $2500 \mathrm{MPC}$ - reduced their quantity by more than $30 \%$ of the control. The decreasing in the quantity of amylolytic bacteria under the action of the highest dose of contamination (10.000 MPC) ranged from 46.8 to $61.2 \%$ of the control with the highest sensitivity in dark-kastanozem soil (Fig. 3, A). 


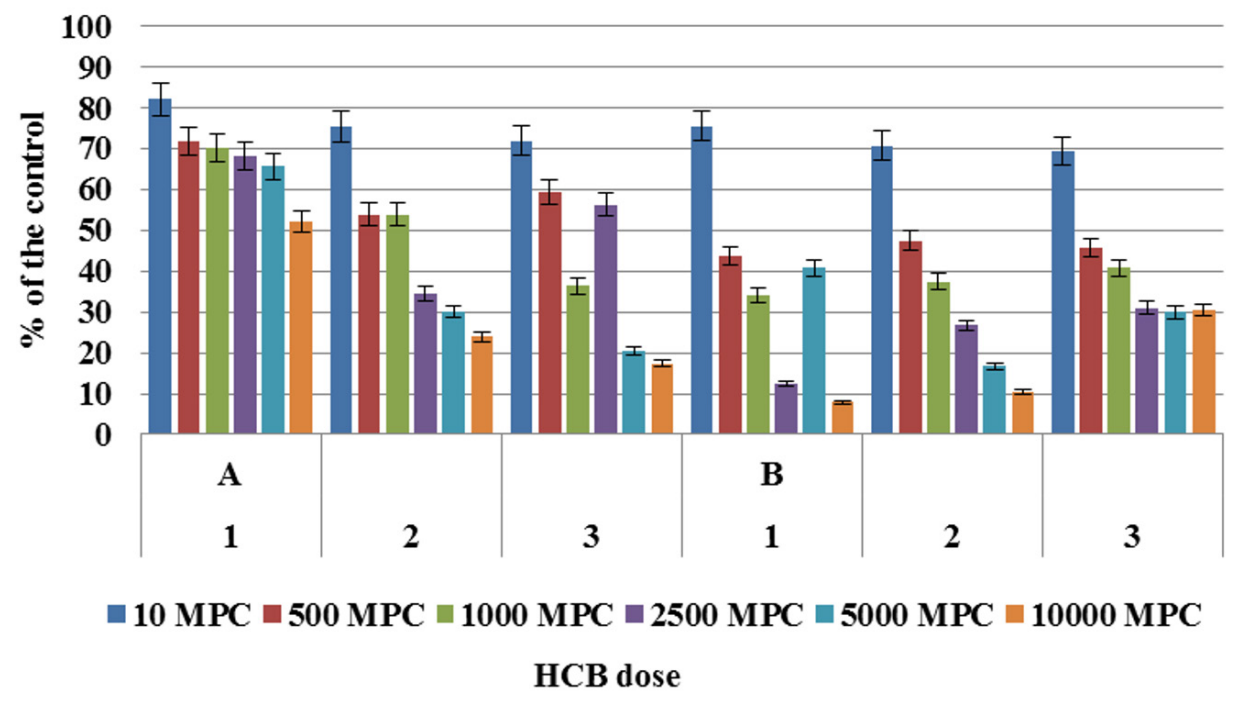

F i g. 2. The quantity of phosphate-mobilizing bacteria (A) and streptomycetes (B) under the action of different HCB doses in chernozem (1), dark-kastanozem (2), and sod-podzolic (3) soils

Nitrogen-fixing and oligonitrotrophic bacteria play an important role in the nitrogen regime optimizing of soils. The quantity of these microorganisms in chernozem, dark-kastanozem and sod-podzolic soils decreased, respectively, at the dose of 500 MPC by $43,23.3,22.5 \%$, the middle dose (2500 MPC) - by $51.8,39,22.4 \%$, and the highest dose (10.000 MPC) - 56.9, 58.1, $74.4 \%$ compared to control (Fig. 3, B).

Ammonifying bacteria that transform organic nitrogen-containing compounds prevailed in quantity in dark-kastanozem and sod-podzolic soils at doses of $500-1000 \mathrm{MPC}$, where there was a decrease in their quantity by $25.4-30.8$ and $36.9-$ $44.4 \%$ respectively. Under the action of $\mathrm{HCB}$ dose in the range from 2500 to $10000 \mathrm{MPC}$, the greatest resistance of ammonifying bacteria was observed in sod-podzolic soil where the decrease in the quantity was not more than $54.6 \%$. This group was the most sensitive in chernozem soil - the quantity decreased by $69.2 \%$ (Fig. 3, C).

Soil micromycetes are actively involved in the mineralization of organic residues of plants and animals, as well as in soil formation, synthesizing melanin pigments, which are similar in structure to humic compounds $[15,16]$.

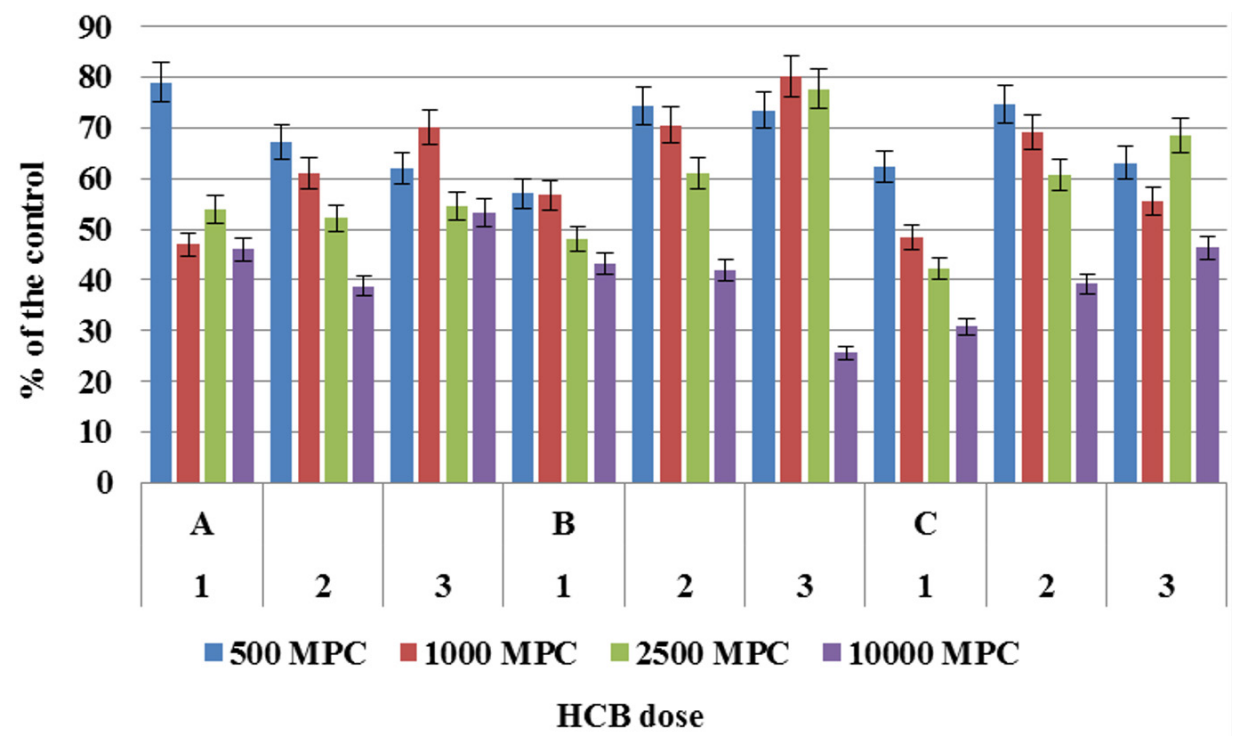

F i g. 3. Quantity of amylolytic (A), oligonitrotrophic, nitrogen-fixing (B) and ammonifying (C) bacteria under the action of HCB in chernozem (1), dark-kastanozem (2), sod-podzolic (3) soils 
Micromycetes showed the greatest resistance to HCB. In chernozem and sod-podzolic soils, their quantity at the action of $\mathrm{HCB}$ doses in the whole studied range from 10 to 10.000 MPC decreased by no more than $28 \%$ compared to the uncontaminated control. Only in dark-kastanozem soil at the highest dose of $10.000 \mathrm{MPC}$, their quantity decreased more than twice - by $62.2 \%$.

Generalized data on the ratio of the quantity of cultivated forms of the studied microorganisms showed that under the action of low contamination doses (10 MPC) the structure of microbial communities remains relatively stable in all soil types. However, the increase in pesticide load causes significant and irreversible changes in the ratio of the component quantity in the microbiocenosis, in particular, in the direction of increasing the micromycetes content and reducing the number of phosphate-mobilizing bacteria (Fig. 4).

Ecological-trophic pedotrophic and nitrogen mineralization coefficients are indicators of soil quality and fertility, which express to some extent the direction of microbiological processes. Changes in the above indices under the action of different $\mathrm{HCB}$ doses in comparison with the control were revealed in the studied soils (Table 1).
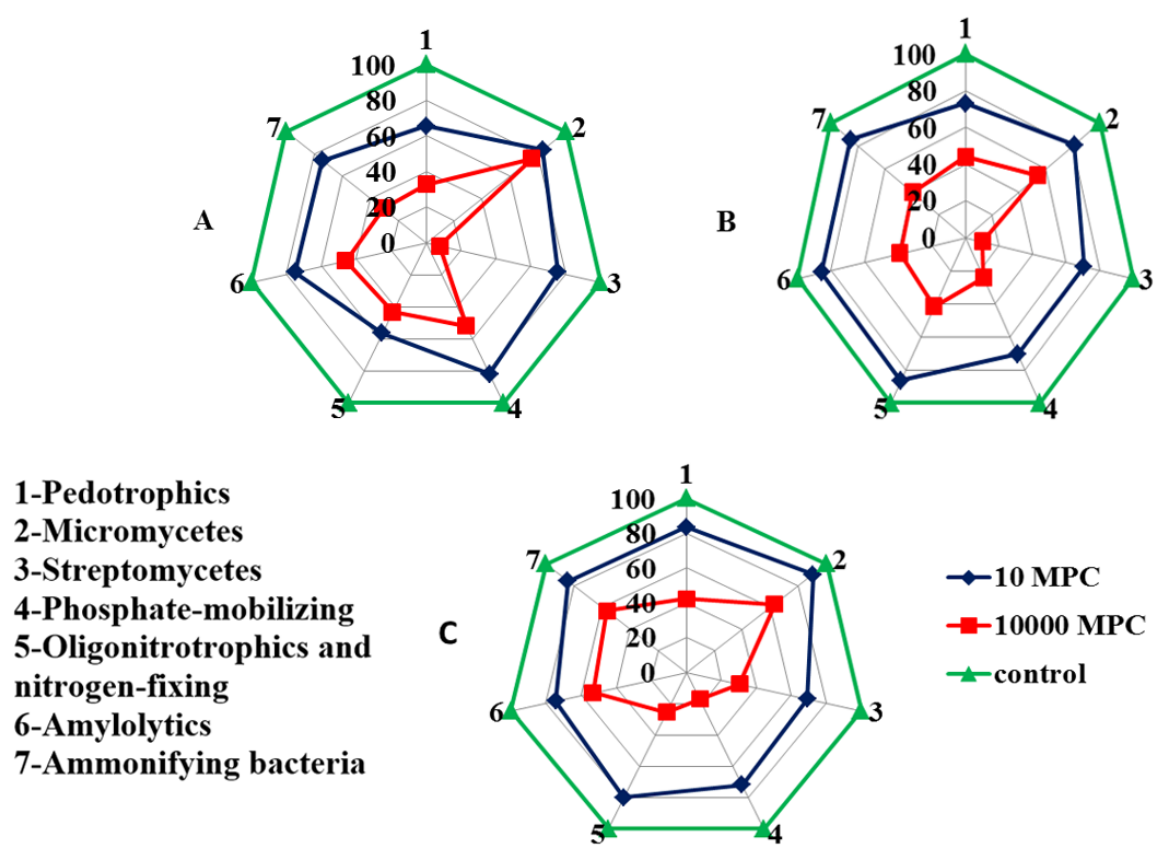

\section{F i g. 4. Effect of HCB on soil microbiocenoses of chernozem (A), dark-kastanozem (B), sod-podzolic (C) soils (\% to control)}

The obtained calculations showed that the processes of soil organic matter transformation in chernozem and sod-podzolic soils differed slightly in the values of pedotrophic coefficients. Under the action of different doses of HCB changes in the coefficients were also insignificant. In the darkkastanozem soil under the action of HCB in doses of $1000-10000$ MPC a decrease in pedotrophic coefficients with increasing pesticide load was noted, which indicated the inhibition of organic matter transformation processes. The indices of mineralization in the conditions of the conducted experiment in all soil types did not exceed 2.0, which confirm the balance of immobilizationmineralization processes in both control and contaminated variants (Table 1).
To determine the dependence between the quantity of each microbial ecological-trophic group and the dose of HCB contamination, a nonparametric Spearman's rank coefficient $(\mathrm{R})$ was calculated, showing a reverse relationship between the above parameters. For soil micromycetes, streptomycetes, phosphate-mobilizing and amylolytic bacteria it was negative $(\mathrm{R}=-0.96 \pm$ $\pm 0.03)$ in all soil types. For pedotrophic, oligonitrotrophic and nitrogen-fixing bacteria, the correlation coefficient ranged from $\mathrm{R}=-0.64 \pm 0.03$ to $\mathrm{R}=-0.96 \pm 0.03$, for ammonifying - from $\mathrm{R}=$ $=-0.67 \pm 0.03$ to $\mathrm{R}=-0.75 \pm 0.03$.

The degree of effect of HCB dose and soil type on the dispersion of the microbial quantity was calculated. In the conditions of the experiment 
the decisive impact (61-95\%) on the quantity of microorganisms had the dose of HCB (factor A), while the effect of soil type (factor B) was less significant.

The total biological activity of soils was characterized by the values of $\mathrm{CO}_{2}$ production rate in native conditions (basal respiration) and with the addition of easily digestible energy substrate (substrate-induced respiration) and assessed the microbial Qr, which is determined by the ratio of the basal respiration rate to the substrate induced rate. Qr is an integral indicator of the soil state and its microbial pool under anthropogenic load. A scale of Qr indicators, which reflects the physiological state of microbial community in certain soil conditions was proposed by Blagodatska et al [11].Thus, the values of Qr in the range of 0.1-0.2 indicate a favorable state of the soil microbial community; Qr values less than 0,1 reflect the reduced activity; Qr values more than $0.2-0.3$ was under adverse climatic or anthropogenic impacts (Table 2).

The content of microbial biomass is one of the main microbiological indicators of soil; data obtained in our study are presented in Table 2 .

\section{Table 1}

Indices of pedotrophic and nitrogen mineralization in different soils

\begin{tabular}{|l|c|c|c|c|c|c|}
\hline \multirow{2}{*}{$\begin{array}{l}\text { Experiment } \\
\text { version }\end{array}$} & \multicolumn{3}{|c|}{ Pedotrophic index } & \multicolumn{3}{c|}{ Index of nitrogen mineralization } \\
\cline { 2 - 7 } Control & Chernozem & Dark-kastanozem & Sodpodzolic & Chernozem & Dark-kastanozem & Sodpodzolic \\
\hline $10 \mathrm{MPC}$ & $2.28 \pm 0.08$ & $2.0 \pm 0.06$ & $2.37 \pm 0.07$ & $1.30 \pm 0.04$ & $1.4 \pm 0.04$ & $1.18 \pm 0.04$ \\
\hline $500 \mathrm{MPC}$ & $1.81 \pm 0.05$ & $1.92 \pm 0.06$ & $2.35 \pm 0.07$ & $1.30 \pm 0.04$ & $1.38 \pm 0.04$ & $1.04 \pm 0.03$ \\
\hline $1000 \mathrm{MPC}$ & $2.16 \pm 0.06$ & $0.85 \pm 0.03$ & $2.12 \pm 0.06$ & $1.60 \pm 0.05$ & $1.25 \pm 0.04$ & $1.16 \pm 0.04$ \\
\hline $2500 \mathrm{MPC}$ & $2.25 \pm 0.07$ & $0.82 \pm 0.02$ & $2.34 \pm 0.07$ & $1.60 \pm 0.05$ & $1.20 \pm 0.04$ & $0.94 \pm 0.03$ \\
\hline $5000 \mathrm{MPC}$ & $2.25 \pm 0.07$ & $0.79 \pm 0.02$ & $2.93 \pm 0.09$ & $1.60 \pm 0.05$ & $1.13 \pm 0.04$ & $1.04 \pm 0.03$ \\
\hline $10000 \mathrm{MPC}$ & $2.73 \pm 0.08$ & $0.62 \pm 0.02$ & $2.85 \pm 0.09$ & $1.90 \pm 0.06$ & $0.79 \pm 0.02$ & $1.38 \pm 0.04$ \\
\hline
\end{tabular}

\section{Table 2}

The soil respiration and microbial biomass under the action of HCB in different soil types

\begin{tabular}{|l|c|c|c|}
\hline \multirow{2}{*}{ Version of the experiment } & \multicolumn{3}{|c|}{ The soil types } \\
\cline { 2 - 4 } & Chernozem & Dark-kastanozem & Sod-podzolic \\
\hline Control & $42 \pm 2.16$ & $37.6 \pm 2.04$ & $37.9 \pm 2.05$ \\
\hline $500 \mathrm{MPC}$ & $37.3 \pm 2.04$ & $29.6 \pm 1.81$ & $33.8 \pm 1.94$ \\
\hline $2500 \mathrm{MPC}$ & $25.4 \pm 1.68$ & $24.9 \pm 1.66$ & $32.2 \pm 1.89$ \\
\hline $10000 \mathrm{MPC}$ & $20.8 \pm 1.52$ & $20.1 \pm 1.49$ & $21.8 \pm 1.56$ \\
\hline \multicolumn{4}{|c|}{ The substrate-induced respiration, $\mathrm{g} \mathrm{CO}_{2} \mathrm{~kg}^{-1} \mathrm{~h}^{-1}$} \\
\hline Control & $111.1 \pm 3.51$ & $112.8 \pm 3.54$ & $84.2 \pm 3.06$ \\
\hline $500 \mathrm{MPC}$ & $82.1 \pm 3.02$ & $79.0 \pm 2.96$ & $58.3 \pm 2.54$ \\
\hline $2500 \mathrm{MPC}$ & $50.9 \pm 2.38$ & $62.2 \pm 2.63$ & $52.2 \pm 2.41$ \\
\hline $10000 \mathrm{MPC}$ & $36.7 \pm 2.02$ & $37.6 \pm 2.04$ & $32.7 \pm 1.91$ \\
\hline \multicolumn{4}{|c|}{ The microbial Qr } \\
\hline Control & $0.38 \pm 0.01$ & $0.33 \pm 0.01$ & $0.45 \pm 0.01$ \\
\hline $500 \mathrm{MPC}$ & $0.45 \pm 0.01$ & $0.38 \pm 0.01$ & $0.58 \pm 0.02$ \\
\hline $2500 \mathrm{MPC}$ & $0.50 \pm 0.02$ & $0.40 \pm 0.01$ & $0.62 \pm 0.02$ \\
\hline $10000 \mathrm{MPC}$ & $0.57 \pm 0.02$ & $0.53 \pm 0.02$ & $0.67 \pm 0.02$ \\
\hline \multicolumn{4}{|c|}{ The microbial biomass, $\mathrm{g} \mathrm{kg}$} \\
\hline Control & $47.7 \pm 2.3$ & $51.9 \pm 2.4$ & $31.9 \pm 1.88$ \\
\hline $500 \mathrm{MPC}$ & $30.9 \pm 1.85$ & $34.1 \pm 1.94$ & $17.0 \pm 1.37$ \\
\hline $2500 \mathrm{MPC}$ & $17.6 \pm 1.4$ & $25.4 \pm 1.68$ & $13.8 \pm 1.24$ \\
\hline $10000 \mathrm{MPC}$ & $11.0 \pm 1.1$ & $12.1 \pm 1.16$ & $7.5 \pm 0.91$ \\
\hline
\end{tabular}


Discussion. Considering that contamination of soils with chemical xenobiotics is becoming threatening today, the study of their impact on the soil microbiota attracts the attention of many researchers. Particularly dangerous and banned for use today are organochlorine pesticides, which have accumulated in the environment as a result of their widespread use in previous years, from the forties (40s) to the end of the $20^{\text {th }}$ century $[3,17]$. Known literature data about the effect of the most common organochlorine pesticides on the soil microbiota indicate that microbial communities are very sensitive to these compounds reflecting in the quantity and functional activity [18]. Researchers from many countries around the world, such as Canada, Germany, Pakistan and India, have paid attention to the impact of pesticides, including organochlorines, on the soil microbiota. The authors noted a decrease in the quantity of bacteria, actinomycetes and micromycetes in the soil as one of the responses to pesticide load [19, 20]. In addition to the above, Indian researchers also found a decrease in the quantity of cellulolytic and phosphate-mobilizing microorganisms in response to the presence of organochlorine insecticides DDT, endosulfan, hexachlorocyclohexane [21]. The organochlorine pesticides lindane and dildrin have been shown to be highly toxic for the representatives of the genus Nitrosomonas, Nitrobacter and Thiobacillus [22].

Local pollution areas near pesticide landfills are especially dangerous. The soil microbiota near an abandoned insecticide factory in Wuhan was studied, where synthetic preparations based on DDT, hexachlorocyclohexane, chlorobenzene and 1,4-trichlorobenzene were manufactured [23]. The level of contamination by residues of these pesticides was found to be one of the dominant factors influencing the structure and biodiversity of the microbiocenosis, significant changes of which have been recorded at doses of pesticide load of $1 \mathrm{mg} \cdot \mathrm{kg}^{-1}$ of soil. Rodríguez and Toranzos [24] studied the microbiota of tropical soils (Puerto Rico) under the action of lindane, which was applied at a dose of $100 \mathrm{mg} \cdot \mathrm{kg}^{-1}$ of soil. In the first 2 weeks of observations, the total quantity of microorganisms decreased by $50 \%$, which was correlated with a decrease in the rate of using carbohydrate substrate. When compared with our studies, we registered that at the doses from 160 to $800 \mathrm{mg} \cdot \mathrm{kg}^{-1}$ of soil the quantity of sensitive indicator phosphate-mobilizing bacteria decreased by $70-90 \%$, and more stable amylolytic, nitrogen- fixing and ammonifying microorganisms - by $30-50 \%$.

To a large extent, researchers have paid attention to the studying the effect of organochlorine pesticides on the biological activity of soils. The pesticides are known to affect the microbiocenosis, disrupt such vital processes as respiration, biosynthetic reactions $[25,26]$. Data on changes in microbial biomass under the action of organochlorine compounds are contradictory. Thus, in research with experimental soil contamination (Shandong Province) with endosulfan during 9 days of incubation of samples was observed a decrease in fungal biomass by $47 \%$, while bacterial biomass increased by an average of $76 \%$ [27]. Our study showed that HCB inhibited the rate of microbial respiration and the accumulation of microbial biomass.

Analysis of the available data in the literature shows that the HCB effect on the soil microbiota has been studied less than other common organochlorine insecticides, such as DDT, hexachlorocyclohexane, and endosulfan. HCB has accumulated in the soil as industrial waste or impurities in the production of some pesticides [28]. Thus, it's part of the total organochlorine pesticides amount in soils may be slightly less than DDT and $\mathrm{HCH}$. For example, Chinese scientists (Hong Kong) studied the presence of organochlorine compounds in woodland, grassland, arable land, wetlands and reclamation land. Five types of banned pesticides have been detected in soils in a range of reductions in their concentrations: $\mathrm{HCH}>\mathrm{DDT}>\mathrm{HCB}>$ endrin $>$ endosulfan [29]. However, in Ukraine there are areas with a high anthropogenic HCB loading [6], so for our country the study of HCB impact on the ecosystem state is relevant and necessary. Data on the negative HCB impact at different doses on the soil microbiota of chernozem, dark chestnut and sod-podzolic soils in Ukraine were obtained for the first time.

Thus, the data available in the literature and the results of our own research indicate that organochlorine compounds, including chlorobenzene, adversely affect microbial groups of different soil types, but the reaction of the individual components of microbiota is different depending on the chemical nature of the toxicant and soil conditions. Data about the specific action of these compounds in different soil types of Ukraine are necessary for the development of appropriate effective rehabilitation means. 
Conclusions. Microbiocenoses of chernozem, dark-kastanozem, sod-podzolic soils in intensive land use systems are vulnerable to $\mathrm{HCB}$ contamination in doses from 10 to 10,000 MPC. The most sensitive phosphate-mobilizing bacteria and streptomycetes can be used as indicators in monitoring of organochlorine contaminated soils. Under the action of pesticide loading, microbial respiration and accumulation of microbial biomass are suppressed. The negative reaction of microbial communities to HCB contamination indicates the need for remediation means to recovery soil microbiota and fertility.

\section{ВПЛИВ ГЕКСАХЛОРБЕНЗОЛУ НА МІКРОБІОЦЕНОЗИ ГРУНТІВ РІЗНИХ ТИПІВ}

\section{М.І. Дімова, Н.А. Ямборко, Г.О. Іутинська}

Інститут мікробіології і вірусології ім. Д. К. Заболотного НАН України, вул. Академіка Заболотного, 154, Київ, 03143, Україна

\section{Резюме}

Екологічні наслідки забруднення грунтів ксенобіотиками, такими як хлорорганічні пестициди, залишаються мало вивченими. Гексахлорбензол $\epsilon$ однією $з$ найпоширеніших хлорорганічних сполук, яка входить до списку стійких органічних забруднень, заборонених до використання згідно Стокгольмської конвенції 2003 року. Актуальним $\epsilon$ дослідження впливу гексахлорбензолу на грунтові мікробіоценози, активність яких є значущою для еколого-функціональних характеристик грунтів. Мета роботи. Визначення впливу гексахлорбензолу на грунтову мікробіоту чорноземного, темно-каштанового і дерново-підзолистого грунтів агроценозів України у інтенсивних системах землеробства. Об'єктом дослідження були мікробні угруповання трьох типів грунтів; предметом дослідження - реакція мікробного ценозу на забруднення різними дозами гексахлорбензолу (ГХБ). Методи. Модельні лабораторні експерименти, мікробіологічні (визначення чисельності мікроорганізмів на агаризованих поживних середовищах), хімічні (адсорбційний метод для дослідження базального і субстрат-індукованого дихання грунтової мікробіоти), статистичні. Результати. Визначено зворотню залежність чисельності мікроорганізмів окремих груп від дози забруднення, що підтверджено значеннями коефіцієнтів кореляції Спірмена у діапазоні від $-0,64$ до $-0,96$. У досліджених грунтах всіх типів найбільш чутливими до гексахлорбензолу були фосфатмобілізувальні бактерії і стрептоміцети. Кількість фосфатмобілізувальних бактерій за максимальної дози забруднення 10000 гранично допустимих концентрацій (ГДК) зменшувалась у чорноземному, темно-каштановому і дерново-підзолистому грунтах відповідно на 48, 75 і 83 \% від контролю. Кількість стрептоміцетів за дії доз 500-10000 ГДК знижувалась до критичних показників і становила 8-30 \% від значень у незабрудненому контролі. Максимальне зменшення чисельності олігонітротрофних і азотфіксувальних бактерій (на 57-74 \%) у досліджуваних грунтах відмічено за дії найвищої дози забруднення 10000 ГДК. Кількість амілолітичних бактерій за дози 500 ГДК зменшувалась на 21-38 \%, за 10000 ГДК - на 47-61 \% від контролю. Амоніфікувальні бактерії переважали за чисельністю у темно-каштановому і дерново-підзолистому грунтах при дозах 500-1000 ГДК, де відмічали зниження їх кількості на 25,4-30,8 та 36,9-44,4 \% відповідно. Найбільшу резистентність амоніфікаторів спостерігали у дерново-підзолистому грунті. Грунтові мікроміцети продемонстрували найбільшу стійкість до гексахлорбензолу. У чорноземному і дерново-підзолистому грунтах їхня чисельність за дії ГХБ у всьому досліджуваному діапазоні доз зменшилась не більше, як на $37 \%$ порівняно з незабрудненим контролем. Вміст мікробної біомаси $є$ одним з основних мікробіологічних індикаторів грунту. За експериментального забруднення різними дозами ГХБ вміст мікробної біомаси зменшувався у 1,5-4,3 рази порівняно 3 контролем. Коефіцієнти педотрофності засвідчили про те, що процеси трансформації органічної речовини у чорноземному і дерново-підзолистому забруднених грунтах несуттєво відрізнялись від контролю, у темно-каштановому грунті зі збільшенням пестицидного навантаження вони пригнічувались. Індекси мінералізації азоту не перевищували 2,0, що свідчило про збалансованість процесів імобілізації-мінералізації як у контрольних, так і забруднених варіантах. Висновки. Мікробіоценози чорноземного, темно-каштанового, дерново-підзолистого грунтів у інтенсивних агроценозах вразливі до забруднення гексахлорбензолом у дозах від 10 до 10000 ГДК. Найбільш чутливі - фосфатмобілізувальні бактерії і стреп- 
томіцети - можуть бути використані як індикаторні у моніторингу грунтів, забруднених хлорорганічними пестицидами. Під дією пестицидного навантаження пригнічуються мікробне дихання i накопичення мікробної біомаси. Негативна реакція мікробних угруповань на забруднення гексах-

1. Lovecka P, Pacovska I, Stursa P, Vrchotova B, Kochankova L, Demnerova K. Organochlorinated pesticide degrading microorganisms isolated from contaminated soil. New Biotechnol. 2015; 32(1):26-31.

2. Liang H, Chen A, Li Z, Ashraf M, Ding C. Influences of 1,2-dichlorobenzene on Bacterial Community Structure in Wetland Soil. Sains Malaysiana. 2016; 45(1):129-134.

3. Gill H, Garg H. Pesticides: Environmental Impacts and Management Strategies. PesticidesToxic Aspects. 2014; p. 187-197.

4. Lovecka P, Vondracek J, Janu P, Demnerova K. Organochlorine pesticides - effect on microbial diversity and their ecotoxity. Book of proceedings - 6th International Symposium on Biosorption and Biodegradation. Bioremediation - BioBio 2017; 25-29(June):30-36.

5. Yamborko NA, Iutinskaya GO, Levchuk IV, Pidrrus AA. Component composition of pollutants and state of microbial cenosis of soil of landfill for burial of chlororganic wastes. Mikrobiol. Z. 2013; 75(3):24-31.

6. [Supplement No. 29 to the List of Sanitary and Hygienic Norms "Permissible levels of pesticides in agricultural raw materials, food, air of the working area, atmospheric air, water of reservoirs, soil"]. Resolution of the Chief State Sanitary Physician of Ukraine of June 10, 1995 No. 15. Approved Resolution No. 134 of the Chief State Sanitary Physician of Ukraine of July 3, 2000. Ukrainian.

7. Gudz SP, Hnatush SO, Bilinska IS. [Practice on microbiology]. Lviv: LNAU edition. -80 p. Ukrainian.

8. Tepper EZ, Shilnikova VK, Pereverzeva GI. [Practice on microbiology. Educational manual for high schools]. Shilnikova VK, editor. M: Drofa, 2004. 256 p. Russian. лорбензолом свідчить про необхідність проведення заходів ремедіації для відновлення мікробіоти і родючості грунтів.

Ключові слова: гексахлорбензол, мікробні угруповання, базальне і субстрат-індуковане дихання, мікробна біомаса.

9. Anderson TH, Domsch KH. A physiological method fo the quantitative measurement of microbial biomass in soils. Soil Biol Biochem. 1978; 10(3):215-221.

10. Nakamoto T, Wakahara S. Development of Substrate Induced Respiration (SIR) Method Combined with Selective Inhibition for Estimating Fungal and Bacterial Biomass in Humic Andosols, Plant Prod Sci. 2004; 7(1):70-76.

11. Blagodatskaya EV, Ananyeva ND, Myakshina TN. [Characterization of the state of the microbial community of the soil in terms of metabolic coefficient]. Soil Sci. 2015; 2:205-210. Russian.

12. Mishustin EN. [Successes in developing the principles of microbiological diagnosis of soil conditions]. In: Mishustin EN, Runov EV, editors. Successes of modern biology. M.: AN USSR. 1957; 44:256-267. Russian.

13. Nikitin DI. [Processes of self-cleaning environment and plant parasites]. In: Nikitin DI, Nikitina VS, editors. M.: Science; 1978. 205p. Russian.

14. Bilyavska LO, Kozyrytska VYe, Kolomiets YuV, Babich OA, Iutynska GO. [Phytoprotective and growth regulatory properties of metabolic preparations based on soil streptomycetes]. In: Reports of the National Academy of Sciences of Ukraine. 2015; 1:131-137. Ukrainian.

15. Carlile MJ, Watkinson SC, Gooday GW. The Fungi. 2nd Ed. Academic press. San Diego. San Francisco. NewYork. Boston. 2001. 588 p.

16. Joergensen R.G. Wichern F. Quantitative assessment of the fungal contribution to microbial tissue in soil. Soil Biol Biochem. 2008; 40:29772991.

17. Kaliaa A, Gosalb SK. Effect of pesticide application on soil microorganisms. Arch Agron Soil Sci. September 2011; 57(6):569-596.

18. Gupta RP, Singh J, Sultan MS, Hujan RK, Gosal SK, Sahota H, Sharma S. Impact of pesticides 
on soil biota and non-target organisms in rice wheat cropping system. 41st Annual Conference of AMI. Birla Research Institute, Jaipur. India. 2000.

19. Hussain S, Siddique T, Saleem M, Arshad M, Khalid A. Impact of pesticides on soi lmicrobial diversity, enzymes, and biochemical reactions. Adv Agron. 2009; 102:159-200.

20. Imfeld G, Vuilleumier S. Measuring the effects of pesticides on bacterial communities in soil: a critical review. Eur J Soil Biol. 2012; 49:22-30.

21. Niti C, Sunita S, Kamlesh K, Rakesh K. Bioremidiation, an emerging technology for remediation for pesticides. Res J Chem Environ. 2013 April; 17(4):88-91.

22. Odokuma LO, Osuagwu C. Tolerance of chemolithotrophic bacteria to organochlorine, organophosphate and carbamate pesticides. J Agr Environ Eng Technol. 2004; 1(1):7-15.

23. Du Y, Sun G, Yin J, Jiang Y, Zhang D, Jiang B, $\mathrm{Hu}$ J. Response of microbial communities to different organochlorine pesticides (OCPs) contamination levels in contaminated soils. Chemosphere. January 2019; 215:461-469.
24. Rodríguez RA, Toranzos GA Stability of bacterial populations in tropical soil upon exposure to Lindane. Int Microbiol. 2003; 6(4):253-8.

25. DeLorenzo ME, Scott GI, Ross PE. Toxicity of pesticides to aquatic microorganisms: a review. Environ Toxicol Chem. 2001; 20:84-98.

26. Floch C, Chevremont AC, Joanico K, Capowiez Y, Criquet S. Indicators of pesticide contamination: Soil enzyme compared to functional diversity of bacterial communities via Biolog. Ecoplates. Eur J Soil Biol. 2011; 47:256-263.

27. Xie H, Gao F, Tan W, Wang SG. A short-term study on the interaction of bacteria, fungi and endosulfan in soil microcosm. Sci Total Environ. $2011 ; 412: 375-379$.

28. Wang H, Cao X, Li L, Fang Z, Li X. Augmenting atrazine and hexachlorobenzene degradation under different soil redox conditions in a bioelectrochemistry system and ananalysis of the relevant microorganisms. Ecotox Environ Safe. 2018; 147:735-41.

29. Zhang HB, Luo YM, Zhao QG, Wong MH, Zhang GL. Residues of organochlorine pesticides in Hong Kong soils. Chemosphere. 2006; 63(4):633-641.

Received 20.05.2020 